\title{
Pemanfaatan Teknologi Berbasis Aplikasi Dalam Pencegahan HIV pada Remaja di Wilayah Kerja Puskesmas Tangerang Selatan
}

\author{
Daryanto ${ }^{1}$, Taryudi ${ }^{2}$ \\ 1,2Fakultas Teknik, Univeristas Negeri Jakarta \\ email: ${ }^{1}$ daryantoaiz@gmail.com, 2taryud@yahoo.com
}

\begin{abstract}
Abstrak
Human immunodeficiency virus (HIV) merupakan masalah kesehatan global karena penyebarannya yang sangat cepat dan sulit untuk dideteksi. Penyebaran HIV berjalan secara "silence", sulit dideteksi secara langsung karena timbul gejala penyakitnya itu baru akan muncul pada 10-15 tahun setelah tertular, hal ini menjadi penyebab jumlah HIV semakin hari semkain meningkat terutama pada remaja. Tujuan dari kegiatan ini adalah untuk mengembangkan pusat informasi dan konseling dengan menerapkan teknologi informasi mengenai HIV dekat dengan masyarakat sehingga masyarakat memiliki soft skill dan hard skill yang tepat untuk memproteksi diri mereka terhadap bahaya dari penularan HIV. Metode yang digunakan berdasarkan kerangka pemecahan masalah, yaitu pertama dilakukan peningkatan kapasitas pengetahuan dan keterampilan remaja dalam pencegahan HIV melalui penyuluhan, pelatihan, pendidikan, dan pembinaan. Kemudian, penerapan aplikasi di mobile phone untuk sebagai upaya promosi dan preventif terhadap HIV. Selanjutnya, pembentukan kader HIV beserta pusat informasi dan konseling yang teintegrasi dengan sistem pelayanan di puskesmas. Tahap terakhir adalah pembinaan untuk keberlangsungan program melalui sistem evaluasi dan monitoring. Setelah dilakukan program terjadi peningkatan pengetahuan dan keterampilan remaja dalam pencegahan HIV. Program ini merupakan suatu pendekatan yang bebasis school-based HIV prevention yang beroritasi pada peningkatan skill remaja dalam mengurangi resiko penularan HIV.
\end{abstract}

Kata Kunci: HIV, Remaja, Pencegahan, Mobile Apps

\begin{abstract}
Human immunodeficiency virus (HIV) is an important public health issues because of its rapid spread and is difficult to detect. The spread of HIV goes "silence", meaning that the transmission of HIV from one person to another is not seen directly because the symptoms of the disease will appear 10-15 years after being infected, this is the reason the number of HIV is increasing day by day. The aim of this activity is to develop an information and counseling center by applying information technology on to improve knowledge and practice toward HIV preventions. The method that will be used is based on a problem-solving framework, namely first, community empowerment was carried out to increase knowledge and practice toward HIV preventions through counseling, training, education and coaching. Then, the application of
\end{abstract}


applications on mobile phones as promotional and preventive efforts against HIV. Furthermore, the formation of HIV cadres along with an information and counseling center that is integrated with the service system at the Puskesmas. The last stage is guidance for the sustainability of the program through an evaluation and monitoring system. From the results of the program implementation, it was found that the knowledge and skills of adolescents in HIV prevention were increased, especially through sexual intercourse. This program is a school-based HIV prevention approach that focuses on improving adolescent skills in reducing the risk of HIV transmission.

Keywords: HIV, Youth, Prevention, Mobile Apps.

\section{Pendahuluan}

Human immunodeficiency virus (HIV) merupakan masalah kesehatan yang berdampak terhadap perkembangan suatu bangsa. Di Indonesia, prevalensi HIV tertinggi di wilayah Asia yaitu sebesar 0,5\% (UNAIDS, 2016). Jumlah penderita HIV di Indonesia meningkat secara signifikan dari 5.846 pada tahun 2004 menjadi 291.465 pada tahun 2016 dan yang sudah terdiagnosa acquired immunodeficiency syndrome (AIDS) dari 4.973 ditahun 2004 menjadi 82.556 pada tahun 2019 dengan angka kematian sebanyak 14.234 jiwa ( Kementrian Kesehatan RI, 2019). HIV di Jawa Barat dan Banten menempati urutan ke-4 tertinggi di Indonesia dengan jumlah 18.727 dan 4.919 yang sudah terdiagnosa AIDS sebanyak ( Kementrian Kesehatan RI, 2019).

Tangerang merupakan salah satu kota tertinggi jumlah penderita HIV di Banten dengan angka sebanyak 3.912 jiwa dengan rata - rata 200 sd 400 kasus baru pertahunnya. Status HIV di Kota Tangeran termasuk dalam kategori terkonsentrasi dimana yang tediagnosa HIV hanya pada kelompok khusus seperti homeseksual, pengguna narkoba suntik, dan pekerja seksual. Berdasarkan pekerjaan terbanyak pada pekerja swasta, $(26,65 \%)$, Wiraswasta $(16,75 \%)$, dan tidak bekerja $(14,90 \%)$. Berdasarkan usia, sebanyak 5.714 usia 15-19 tahun terinfeksi HIV dan 2.208 diantaranya terdiagnosa AIDS. Menurut (Kementrian Kesehatan RI, 2019) usia paling banyak jumlah HIV berada pada rentang 20-29 tahun yakni sebesar 31,8\%. Mempertimbangkan masa inkubasi HIV yang cukup lama, sehingga dimungkinkan sekali bahwa sebetulnya seseorang sudah terinfeksi HIV pada usia remaja. Sehingga, pencegahan HIV perlu dimulai secara dini pada anak usia remaja, bukan hanya pencegahan pada kelompok khusus resiko HIV. Masa remaja merupakan masa mencari identitas dan sudah muncul ketertarikan secara seksual terhadap lawan jenis.

Tangerang memiliki karakteristik tersendiri dibanding kawasan pemukiman penduduk daerah lainnya. Di kawasan ini, banyak dihuni oleh para pelajar, mahasiswa, dan wisatawan. Kehadiran mahasiswa tentunya tidak hanya mendatangkan dampak positif, namun ada juga dampak negatifnya. Hal tersebut berdampak terhadap perubahan perilaku yang beresiko terhadap penularan penyakit HIV seperti seks bebas, penggunaan zat-zat adiktif terlarang, perilaku m enyimpang lainnya. Penularan HIV dilaporkan paling banyak melalui seks bebas baik 
pada remaja atapun yang sudah berkeluarga dan melalui penggunaan narkoba suntik secara bergantian. Dalam pergaulan remaja, seks bebas sudah menjadi hal biasa, terutama ciuman. Kasus narkoba sudah pernah terjadi dan terlaporkan. Selain itu, seperti yang dilansir oleh suatu media cetak lokal pada bulan Mei 2019, terungkap adanya pesta seks di rumah kos mahasiswa di kawasan tersebut, sementara itu di tempat yang berbeda juga ditemukan adanya pesta narkoba di kalangan mahasiwa. Hal tersebut menjadi pintu gerbang utama dalam penyebaran penyakit HIV. Sehingga dibutuhkan upaya yang agresif dalam pencegahan dan penanggulangan HIV. Selain tingginya resiko penularan penyakit HIV diwilayah ini, peran tenaga kesehatan dalam tindakan pencegahan masih sebatas pendidikan kesehatan atau sosialiasasi singkat melalui iklan atau pamflet. Hal tersebut berdampak pada banyaknya kesalahfahaman informasi mengenai HIV terutama dalam hal pencegahannya. Sehinga dibutuhkan strategi pendidikan kesehatan mengenai HIV yang komprehensif dengan mempertimbangkan kemajuan teknologi yang mudah diakses dan reliable.

Tujuan dari program ini adalah memberikan edukasi dengan pemanfaatan teknologi berbasis aplikasi dalam pencegahan HIV pada Remaja di Wilayah Kerja Puskesmas Tangerang Selatan. Selain itu dilakuakn pengukuran pengetahuan, sikap, dan perilaku remaja sebelum diberikan pendidikan Kesehatan berbasis aplikasi sebagai data penunjang keberhasilan program.

\section{Metode}

1) Permberdayaan remaja melalui penyuluhan, pelatihan, pendidikan, dan pembinaan kesehatan terutama berkaitan dengan pencegahan HIV. Adapun konten pencegahan HIV berfokus pada peningkatan kapasitas masyarakat dalam hal pengetahuan, sikap, dan perilaku terhadap penularan HIV. Selain itu, program ini juga akan berfokus pada penurunan perilaku beresiko terhadap penularan HIV.

2) Sustainable program: untuk menjaga keberlanjutan program kedepannya akan dilakukan kerjsama secara intensif dengan pihak puskesmas setempat sehingga bisa melakukan pembinaan, monitoring termasuk upgrade informasi-informasi terkini mengenai pencegahan HIV. 


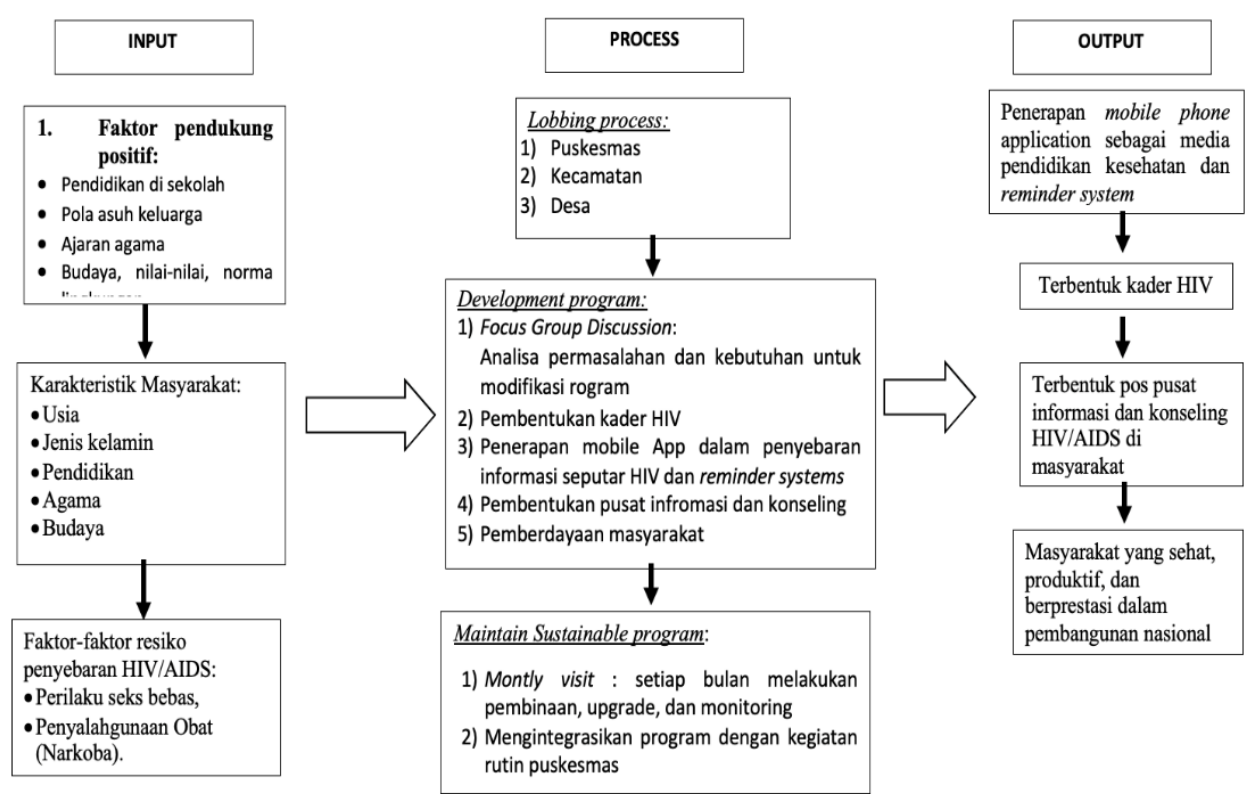

Gambar 1. Metode pelaksanaan program Pemanfaatan Teknologi berbasis Aplikasi dalam pencegahan HIV pada Remaja di Wilayah Kerja Puskesmas Tangerang Selatan

Pada Gambar 1 diatas dijelaskan mengenai metode pelaksanaan program Pemanfaatan Teknologi berbasis Aplikasi dalam pencegahan HIV pada Remaja di Wilayah Kerja Puskesmas Tangerang Selatan. Kegiatan dimulai dengan melakukan identifikasi factor pendukung, karakteristik masyarakat, dan faktor resiko HIV melalui kajian literature dan media masa. Data ini digunakan untuk menrencanakan program yang sesuai dengan karakteristik sasaran pengabdian masyarakat. Setelah itu dilakukan proses perizinan dengan beberapa pihak yaitu puskesmas, kecamatan, dan desa setempat. Kemudia program dikembangkan melalui Focus group discussion dengan steakholder dan remaja untuk mengindentifikasi permasalah dan kebutuhan serta pembentukan kader HIV sebagai penggerak program-program berikutnya. Setelah itu dilakukan proses pendidikan Kesehatan dan pelatihan dalam mengakses informasi melalui aplikasi yang ter-install di handphone. Setelah program selesai, tahap berikutnya adalah pembinaan yang dilakuakn memalui upgrade informasi dan pemantauan remaja dalam penggunaan aplikasi. Sehingga luaran yang diharapkan adalah terbentuknya kader HIV, pusat informais dan konseling HIV, serta masyarakat yang sehat bebas HIV.

\section{Hasil dan Pembahasan}

Aplikasi yang dimanfaatkan untuk program pencegahan HIV pada remaja adalah $H I V$ Info Corner. Aplikasi ini memuat materi edukasi yang komprehensif tentang HIV, perilaku beresiko HIV, dan isu seputar masalah remaja. Selain itu juga, dalam aplikasi ini dilengkapi dengan chat room consulation sehingga remaja bisa bertanya dan berdiskusi langsung seputar HIV dan perliaku beresiko HIV. Remaja dianjurkan untuk mendownload dan menginstal aplikasi HIV Info Corner dan menggunakannya serta membaca informasi atau konten yang terdapat didalamnya. 


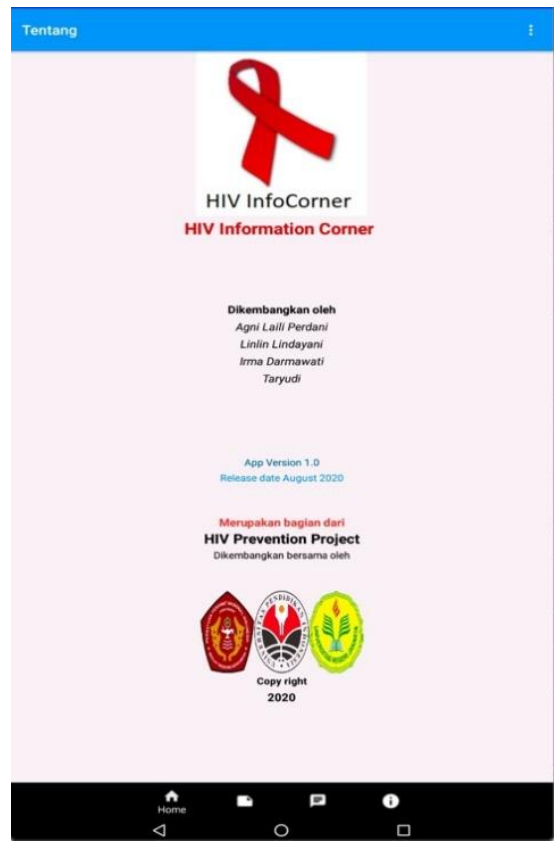

Gambar 2. HIV Info Corner

Sebanyak 30 siswa setuju untuk berpartisipasi dalam pengabdian ini. Sebagian besar siswa $(76.7 \%)$ adalah perempuan dengan usia rata-rata $14.56(\mathrm{SD}=1.56)$ (Tabel 1). Sumber informasi yang sering digunakan oleh siswa adalah sebagian besar $(86.7 \%)$ melalui internet. Sebagian dari siswa $(86.7 \%)$ tahu mengenai HIV tetapi tidak tahu bedanya HIV dan AIDS. Sebagian besar (76.7\%) berpendapat bahwa HIV itu penyakit yang menyeramkan dan sebanyak $76.7 \%$ berpendapat bahwa HIV menular melalui jabat tangan atau bersentuhan.

Table 2. Pengetahuan, sikap, dan perilaku pencegahan HIV pada siswa SMA setelah pelaksanaan

\begin{tabular}{|c|c|c|c|c|}
\hline & Pre-test & Post-test & $p$-values & Nilai Beda \\
\hline & Mean (SD) & Mean (SD) & & \\
\hline Pengetahuan & 12.4 (SD:3.45) & 18.9 (SD:6.21) & 0.001 & 5.2 \\
\hline Sikap & 35.6 (SD:4.98) & 39.2 (SD:4.34) & 0.001 & 4.19 \\
\hline Perilaku & 15.54 (SD:2.5) & 19.9 (SD: 5.03) & 0.04 & 3.98 \\
\hline
\end{tabular}

Pada Tabel 2 terlihat nilai beda sebesar 5.2 untuk pengatahuan, 4.19 untuk sikap, dan 3.98 untuk perilaku (Table 1). Nilai rata-rata pengetahun siswa menjadi 12.4 (SD:3.45), sikap sebesar 35.6 (SD:4.98), dan perilaku sebesar 15.54 dengan standar deviasi sebesar 2.5. Secara detail, lenbih dari $86 \%$ siswa, mereka mengetahui bahwa HIV menular melalui hubungan seksual dan tidak menular melalui berjabat tangan. Sebanyak $90 \%$ siswa mengetahui cara mencegahan HIV dengan prinsip abstinent dan be faith. Bertkaitan dengan sikap dan perilaku, sebagian dari siswa faham bahwa berpacaran itu tidak baik apalagi berciuman atau berpelukan. 
Berdasarkan hasil paired $t$ test didapatkan bahwa program ini efektif dalam meningkatan pengetahuan, sikap, dan perilaku siswa SMA terhadap resiko penularan HIV terutama melalui hubungan seksual ( $p$ value $<0.001$ ).

Program ini didesign dengan kurikulum yang jelas efektif untuk meningkatkan pengetahuan, sikap, dan perilaku remaja mengenai pencegahan HIV. Berdasarkan hasil penelitian yang hampir sama dilakukan di spanyol menunjukan bahwa pendekatan ini efektif dalam meningkatakan pengetahuan, sikap, dan juga perilaku siswa terhadap pencegahan HIV (Morales et al., 2014). Akan tetapi terdapat kelemahan dalam penerapan pendekatanya yang pertama adalah tidak melibatkan komunitas sekitar atau juga kerjasama dengan institusi pendidikan kesehatan untuk keberlajutan program sehingga keberlajutan program tidak ada. Kedua, penelitan ini didesin berdasarkan konsep dari teori yang tentu akan berbeda dengan kondisi remaja. Sehingga, pendekatan ini perlu dimodifikasi dengan community-based partnership dan berdasarkan kondisi dan kebutuhan remaja apalagi Indonesia merupakan negara yang memperlihatkan gotong royong serta berbudaya (Ugarte et al., 2013; Wang et al., 2014).

Pengetahuan, sikap dan perilaku siswa mengenai pencegahan HIV terutama yang berkaiatan dengan penularan HIV sangat penting. Masa remaja merupakan masa mencari identitas dan sudah muncul ketertarikan secara seksual terhadap lawan jenis dan narkoba, karena karena pada masa itu, kaingin tahuan mereka, mencoba sesuatu yang baru, dan mencari identitas sangat dominan sehingga terkadang membuat mereka mudah dipengaruhi (Syamsu, 2011). Sebuah meta-analisi yang melaporkan bahwa dengan dibentuknya peer-educator tennyata terbukti lebih efektif dalam mengurangi perilaku seksual beresiko dikalangan remaja dan biaya yang diperlukan juga murah dibandingkan dengan melibatkan tenaga kesehatan (Ghebreyohans et al., 2015; Kim \& Free, 2008; Medley et al., 2009; Simoni et al., 2011; Tolli, 2012). Meskipun beberapa peneliti sebelumnya sudah menggunakan peer educator akan tetapi materi yang digunakan tidak terstuktur dan hanya meningktakan pengetahuan saja, tidak berfokus pada peningkatan skill sehingga aplikasinya masih tetap menempatkan seseorang berada pada resiko tinggi tertular HIV. Penelitian selanjutnya berfokus pada pengembangan peer educator dengan pemanfaatan teknologi diperlukan untuk keberlajutan program.

\section{Simpulan dan Saran}

Program Pemanfaatan Teknologi berbasis Aplikasi dalam pencegahan HIV pada Remaja di Wilayah Kerja Puskesmas Tangerang SelatanPemanfataan teknologiProgram ini berhasil meningkatkan pengetahuan dan keterampilan remaja dalam pencegahan HIV terutama melalui hubungan seksul. Program ini merupakan suatu pendekatan yang bebasis school-based HIV prevention yang beroritasi pada peningkatan skill remaja dalam mengurangi resiko penulara HIV. Sehingga program pengabdian masyarakat berikutnya diperlukan untuk meningakatkan keberlajutan program seperti melalui pengembangan peer-educator yang terintegrasi dan menggunakan teknologi sebagai media penyampaian dan promosi. 


\section{Daftar Pustaka}

Ghebreyohans, G., Khalil, E. A. G., Tsige, Z., \& Ali, F. (2015). The effect of peer education on peer educators' reproductive health knowledge, attitude, health service use and their personal development. Int J Sci Basic Appl Res, 20(1), 294312.

Kim, C. R., \& Free, C. (2008). Recent evaluations of the peer-led approach in adolescent sexual health education: A systematic review. Perspectives on Sexual and Reproductive Health, 40(3), 144-151.

Kementrian Kesehatan RI. (2018). Profil Kesehatan Indonesia Tahun 2017. Jakarta: Kementerian Kesehatan RI, 170-173.

Medley, A., Kennedy, C., O’Reilly, K., \& Sweat, M. (2009). Effectiveness of peer education interventions for HIV prevention in developing countries: a systematic review and meta-analysis. AIDS Education and Prevention, 21(3), 181-206.

Morales, A., Espada, J. P., Orgilés, M., Secades-Villa, R., \& Remor, E. (2014). The shortterm impact of peers as co-facilitators of an HIV prevention programme for adolescents: A cluster randomised controlled trial. The European Journal of Contraception \& Reproductive Health Care, 19(5), 379-391.

Simoni, J. M., Nelson, K. M., Franks, J. C., Yard, S. S., \& Lehavot, K. (2011). Are peer interventions for HIV efficacious? A systematic review. AIDS and Behavior, 15(8), 1589-1595.

Syamsu, Y. (2011). Psikologi perkembangan anak dan remaja. Bandung: PT Remaja Rosdakarya.

Tolli, M. V. (2012). Effectiveness of peer education interventions for HIV prevention, adolescent pregnancy prevention and sexual health promotion for young people: a systematic review of European studies. Health Education Research, 27(5), 904913.

Ugarte, W. J., Högberg, U., Valladares, E., \& Essén, B. (2013). Assessing knowledge, attitudes, and behaviors related to HIV and AIDS in Nicaragua: A communitylevel perspective. Sexual \& Reproductive Healthcare, 4(1), 37-44.

UNAIDS. (2016). GLOBAL Report: UNAIDS report on the global AIDS epidemic. https://www.unaids.org/sites/default/files/media_asset/jc1510_2008globalre port_en_0.pdf

Wang, K., Fu, H., Longfield, K., Modi, S., Mundy, G., \& Firestone, R. (2014). Do community-based strategies reduce HIV risk among people who inject drugs in China? A quasi-experimental study in Yunnan and Guangxi provinces. Harm Reduction Journal, 11(1), 1-9. 